Nobuo Egami 1951. Inheritance of elytral color and pattern in Phytodecta rubripennis. Jap. Jour. Genet. $26: 141 \sim 144$. (With English résumé p. 144).

\title{
フジハムシにおける斑紋型の遺伝*
}

$\begin{array}{llll} & \text { 江 } \text { 上 信 雄 分類UDC } & 575.11: 575.061 .63: \\ \text { 東京大学理学部動物学教室 } & & \end{array}$

\section{I 緒面}

A.de Zulueta (1925) はスペイン産のフジハムシ Phytodecta variabilis にみられる4つ の斑较型は複対立遗伝子によつて発現するもので，しかもてれが $\mathrm{X} ， \mathrm{Y}$ 雨染色体に含まれて， らわゆる限性遺伝の例であると報じている。魚類を除けば限性遗伝の事実は余り知られていな んので，てれは甚だ特異的な実例として注目すべき結果亡言えよう。そてで筆者はわが国産の

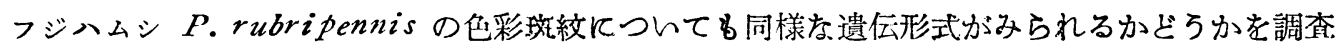
した。

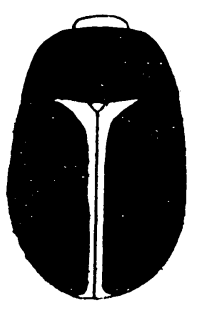

C

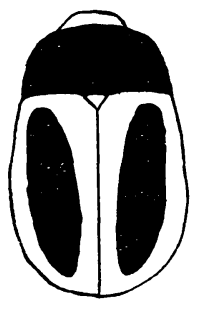

B

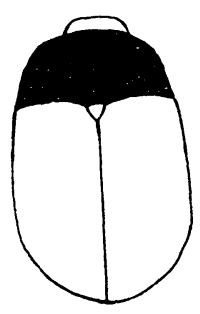

A

フジハムシは翅鞘の全面が赤色を呈し， 図Aに示すように斑紋を持をない。これ に対して図 B，Cのように黒条をもつも のは和名をクロスジフジハムシとんう。 Achard (1924) は後者を前者の変璉とし, P. rubripennis(Baly)var. plagipennis 之記載している。とてろが松村 (1907) が 千虫図解（第58図版，29図，36頁）飞お レて, Baly がてれとは全く別の種に対し て与えた P. nigroplagiata 愦つてク ロスジフジハムシに適用したのが誤敫の\&

ととなり，その後日本人の書いた文献では 第1図翅䩪斑絞の模式困

A. フジハムシ Phytodecta rubripennus

$\mathrm{B}, \mathrm{C}$. クロスジフシハムシ P.r. plagipennis クロスジフジ八ムシに対する学名が間違つをままになり, 徒つてフジハムシ亡クロスジフジハム シはそれぞれ別種として取扱われている。しかし雨者は翅鞘にある黒条の有㫮の外は, 生態学的

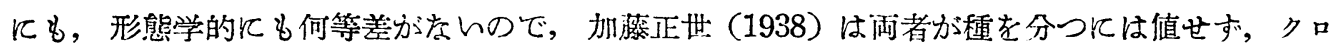
スジフジハムシは P. rubripennis var. nigroplagiata 亡すべをととを主張し, 中根も同 様に両者は同種とすべさてとをのべている。かように本来は変種として記載されたものが,引用 の間違いから別種亡䛊認され，それが実際の観察から再び変種にすべきだとの議論が出ている わけである。しかしてれら同種とすべきだと主張する人るも実際に交配実験を行つているわけ ではなんので，雨者間の遗伀的関係を確めるととはての点からも意味あるてと亡考えられる。

\section{I 交 配 実 験}

1. 材料・方法: 1944 年名古屋才j外小幡原附近で多数のフジ八ムシ (以下 $r$ 之略記) 及びク口 スジフジハムシ (以下 $p$ 之略記) を採集した。てれらはすへて 1943 年に羽化した成体であ る。そのうち若干のものを雌雄各 1 個体ずつ色ふの組合せで同一容器中に入れて交尾産䣙させ

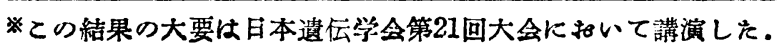


第1表 フシハムシ $(r)$ とクロスジフジハムシ $(p)$ との交配結果

\begin{tabular}{|c|c|c|c|c|c|c|c|c|c|}
\hline \multirow{3}{*}{$\begin{array}{l}\text { 悉 } \\
\text { 号 }\end{array}$} & \multirow{3}{*}{$\mid \begin{array}{c}\mathbf{P} \\
(1943 \text { 年羽化 }) \\
\left.\begin{array}{c}\text { q } \\
\left(\begin{array}{l}\text { 非処 } \\
\text { 女 }\end{array}\right)\end{array}\right) \text { o }\end{array}$} & \multicolumn{3}{|c|}{$\frac{F_{1}}{(1944 \text { 年羽化 })}$} & \multicolumn{4}{|c|}{$\begin{array}{c}F_{2} \\
\text { (1945年羽化) }\end{array}$} & \multirow{3}{*}{$\begin{array}{l}\text { 推 } \\
\text { 定 } \\
\text { 理 } \\
\text { 諭 } \\
\text { 比 } \\
p: r\end{array}$} \\
\hline & & \multirow{2}{*}{ 性 } & \multirow{2}{*}{ 形 筫 } & \multirow{2}{*}{$\left(\begin{array}{l}\text { 用いた個体の同 } \\
\text { 胞の形質分離 }\end{array}\right)$} & \multicolumn{2}{|c|}{ ㅇ } & \multicolumn{2}{|c|}{$\delta$} & \\
\hline & & & & & $p$ & $r$ & $p$ & $r$ & \\
\hline \multirow{2}{*}{1} & $p \times p$ & 우 & $p$ & $(\not p 4, r 0)$ & \multirow{2}{*}{4} & \multirow{2}{*}{0} & \multirow{2}{*}{6} & \multirow{2}{*}{0} & \multirow{6}{*}{$1: 0$} \\
\hline & $p \times p$ & $\hat{\delta}$ & $p$ & $(p 5, r 0)$ & & & & & \\
\hline \multirow{2}{*}{2} & $p \times p$ & 우 & $p$ & $(p 4, r 0)$ & \multirow{2}{*}{11} & \multirow{2}{*}{0} & \multirow{2}{*}{7} & \multirow{2}{*}{0} & \\
\hline & $r \times r$ & $\hat{\delta}$ & $p \varkappa$ & $(p 1, r 11)$ & & & & & \\
\hline \multirow{2}{*}{3} & $r \times p$ & 우 & $p *$ & $(p 5, r 6)$ & \multirow{2}{*}{8} & \multirow{2}{*}{0} & \multirow{2}{*}{7} & \multirow{2}{*}{0} & \\
\hline & $p \times p$ & $\hat{\jmath}$ & $p$ & $(p 12, r 0)$ & & & & & \\
\hline \multirow{2}{*}{4} & $r \times p$ & 우 & $p *$ & $(p 5,16)$ & & & & & \\
\hline & $p \times r$ & $\hat{o}$ & $p \varkappa$ & $(p 11, r 7)$ & 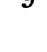 & 2 & 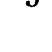 & 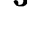 & \\
\hline & $r \times p$ & 우 & $p *$ & $(p 5, r 6)$ & & & & & \\
\hline & $p \times r$ & s & $p \%$ & $(p 4, r 0)$ & 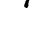 & 2 & 0 & 0 & \\
\hline & $r \times r$ & q & $p *$ & $(p 3, r 5)$ & & & & & \\
\hline & $r \times r$ & $\hat{o}$ & $p \%$ & $(p 3, r 5)$ & 3 & 1 & 4 & 2 & \\
\hline & $p \times p$ & $q$ & $p$ & $(p 5, r 0)$ & & & & & \\
\hline$\gamma$ & $p \times r$ & $\hat{\delta}$ & $r$ & $(p 4, r-2)$ & 1 & 0 & 0 & 0 & \\
\hline & $p \times p$ & 우 & $\not p$ & $(p 4, r 0)$ & & & & & 1,0 \\
\hline 0 & $p \times r$ & $\hat{o}$ & $r$ & $(p 4, r 2)$ & 0 & 0 & 0 & 0 & 100 \\
\hline & $r \times r$ & ㅇ & $r$ & $(p 3, r 5)$ & & & & & \\
\hline 7 & $p \times p$ & $\hat{\delta}$ & $p$ & $(p 11, r 0)$ & 12 & 0 & 15 & 0 & \\
\hline & $p \times p$ & 우 & $p *$ & $(p 12, r 0)$ & & 0 & & $\pi$ & \\
\hline 10 & $r \times p$ & $\hat{\delta}$ & $r$ & $(\not p 2, r 4)$ & 8 & 0 & 0 & 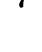 & \\
\hline & $r \times r$ & $q$ & $r$ & $(p 0, r 11)$ & & & & & 1.1 \\
\hline$\Lambda \perp$ & $r \times p$ & $\delta$ & $p \circledast$ & $(\not p 5, r 6)$ & 4 & 5 & 4 & $\gamma$ & 1.1 \\
\hline & $p \times r$ & 우 & $r$ & $(p 4, r 4)$ & & & & & \\
\hline 12 & $r \times p$ & $\hat{o}$ & $p *$ & $(p 5, r 6)$ & 0 & 4 & 2 & 4 & \\
\hline 13 & $r \times r$ & 우 & $r$ & $(p 0, r 4)$ & 0 & 8 & 0 & 6 & \\
\hline 10 & $r \times r$ & $\hat{0}$ & $r$ & $(p 0, r 4)$ & & & & & \\
\hline 14 & $p \times r$ & 운 & $r$ & $(p 4, r 5)$ & 0 & 3 & 0 & 8 & \\
\hline 14 & $r \times r$ & $\hat{o}$ & $r$ & $(p 0, r 11)$ & & & & & $0: 1$ \\
\hline 15 & $p \times p$ & $q$ & $r$ & $(p 9, r 4)$ & 0 & 5 & 0 & 5 & \\
\hline & $p \times r$ & $\hat{0}$ & $r$ & $(p 11, r 5)$ & 0 & 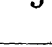 & 0 & & \\
\hline 16 & $p \times p$ & $q$ & $r$ & $(p 9, \quad r 4)$ & 0 & 10 & 0 & 9 & \\
\hline & $p \times p$ & $\delta$ & $r$ & $(p 9, r 4)$ & & & & & \\
\hline
\end{tabular}

$\mathrm{F}_{1} \not$ ※はへテロと推定されるすの 
た。野外で交尾中のものはそのまま組にして持帰り，他の個体之分離して産卵させた。それら から生じた子を検䍒したが，雌親の非処女性のため遗伝関係が不明であつたのでさらにその子 を翌年迄飼育して，生を残つをものをあらりる組合せで交配を行んそのうち16 組におんて子を 得るととに成功した。

2. 実験結果：交配実験の結果を整理して第1表て表記した。第】年目には採集してきた雌 が必ずしも処女でなく，多くの雄と交尾していたため， $F_{1}$ の分離は不規則であつたが，第 2 年目に生じた子は有意義な結果を示した。すなかち， $\mathrm{F}_{1}$ の $p \times p$ の $\mathrm{F}_{2}$ は $p$ ばかり (No.1 3)

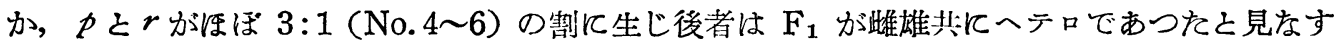
ととができる。次に $p \times r$ 又は $r \times p$ 組合せでは， $\mathrm{F}_{2}$ は $p$ ばかり (No.7〜9)か，pとrが約 半数ずつ生ずるが，てれは親の $p$ がへテロの場合であろう。而して $r \times$ の組合せ(No. 13〜16) では決してpの子を生じないてとが一目してわかる。

3. 結論: 以上の結果から，クロスジフジハムシに見られる黒条は常染色体上飞占位する一つ の単純顕性遺伝子によつてあらわれるものであるてとが判定され，フジ八ムシと同一種である こょも疑んなん。

\section{III クロスジフジハムシの出現頻度}

$p$ と $r$ 㑑然の集団におんては，地域により異つた此率でまじつて生活している。未だ充 分の資料を集めるこよがでをないが，現在までに知り得た結果を第 2 表に示した。名古屋附近

第 2 表 フジハムシ $(r)$ とタロスジフジハムシ $(p)$ との出現頻度

\begin{tabular}{|c|c|c|c|c|c|c|c|c|}
\hline 採 & 集 & 地 & (県) & $r$ & $p$ & 採集 & & 筲 \\
\hline 弘 & & 前 & (青 森) & $\mathrm{O}$ & $\times$ & 小山内 & & 実 \\
\hline 五 & 日 & 市 & (東 京) & $\mathrm{O}$ & $x$ & 片 倉 & 康 & 寿 \\
\hline 井 & の & 頭 & (東 京) & $\mathrm{O}$ & $\times$ & 江 上 & 信 & 婎 \\
\hline 石 & 神 & 井 & (東 京) & $9 / 10$ & $\mathrm{I} / 10$ & 加 藤 & 正 & 世 \\
\hline 茂 & & 原 & (千 葉) & 0 & $x$ & 江 上 & 信 & 雄 \\
\hline 横 & & 浜 & (神奈川) & $19 / 20$ & $1 / 20$ & 江 上 & 信 & 雄 \\
\hline 野 & & 尻 & (長 野) & 0 & $x$ & p 根 & 猛 & 产 \\
\hline 小 & 幡 & 原 & (愛 知) & 247 & 327 & 江 上 & 信 & 雄 \\
\hline 名 & 古 & 屋 & (愛 知) & 148 & 176 & 家 城 & & 司 \\
\hline 湯 & の & 山 & (三 重) & 多 & 少 & 江 上 & 信 & 雄 \\
\hline
\end{tabular}

○は分布確実， × は未発見を示す

では は発見されていない。

\section{IIII 変異とその遺 伝 性}

多数の $p$ を観察すれば，その黒条のうちにはかなりの栾異がある。図 $\mathrm{B}$ 及び C はその広狭両 極端のものを示したが，ての中間には大体連続的に色及の程度のものがるられる。今日まで見 ていたとてろではてのゆは遺伝する傾向があるようで，おそらく複対立遺伝子が多数関与して レるものと思われる。 
pにおんても，ノにおんても黒条さは関係然く翅の全面が黒ずんでんるものを見るてよがあ る。一般に飼育したものは野外のものより黒化の傾问があり, 特に小型容器中で育てたものに 多ん。そてで湿度が関係するのではないか之考え, 東京産の $r$ を用いて, 同一卵塊中の卵を 2 群 几分け, 一方は多湿他は普通の条作で成体まで飼育した結果, 多湿区におんて黒化が強くみら れた。乙の他にも温度その他の環境条件が影響与るものと思われるが，乙の翅鞘全面にわたる 暗色化の傾向は外的条作飞基因するとてろが多んてとは明らかである。またての事実はたとえ rの翅鞘におんても黒色色素を形成する能力を持つてとを意味している点でも興味深ん。 最後に翅朝の地色そのものにも変異のあるととを指摘する。名古屋近郊, 東京近郊のものは 大体赤色であるが，湯の山 (三重県) 産のものは著るしく黄色味が強く，一見して色彩の異る てとがかかる。しかし未だ中間的の色調をもつものは見てんなん。てれは卵から同一条作の下 で両地のものを飼育をしても，それぞれの特性を失わなんてとからみて遗伝的形質之推是され るが，未だ交配実験を行つておらない。てれらの点は更に明らかにすべさ点之将える。

てい研究にあたり, 種名の恰討には中根喃彥氏, 材料の採集その他には大沢省三氏, 飼育に際しては家城 司氏にそれぞれ和世話になつた。これら 3 氏及び各地の本種の分布に関して和らせ下さつた方々に知して 感謝する。

文 献

Achard, J. 1924. Les phytodecta et leurs variations. Espèces et variétés nouvelles. Rectifications synonymiques. Čas. Čs. Spol. Ent. 21.

江上信雄 1945. フジハムシとクロスジフジハムシの鞘翅色彩・斑紋の䦗題. 愛知の昆虫誌 5.

Zulueta, A. de. 1925. La herenica ligada al sexo en el co'eotero Phytodecta variabilis. Eos 1. (Abstr. Resumpt. Gen. 3.)

\section{Résumé}

Zulueta (1925) reported that four elytral pattern-types were inherited under the mode of "sex-limited inheritance" in the Spanish leaf-beetle, Phytodecta variabilis.

The Japanese species, P. rubripennis has no pattern (Fig. 1, A), but P. r. var. plagipennis has a considerable black stripe on each elytron (Fig. 1, B, C). So the writer has crossed between these two varieties with all combinations, to know the law of inheritance. The results obtained are listed in Table 1. From these data, it is no doubt that the stripe in $P$. r. var. plagipennis is due to a single autosomal dominant gene. Beside this fact, the variations of the elytral color and the width of the black pattern are discussed in this paper. 